E ISSN: 2622-223X

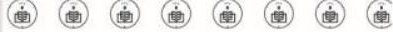

P ISSN: 2598-7607

Vol. II No. 01 (Maret - September) 2017

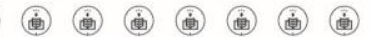

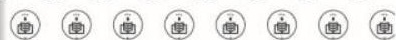

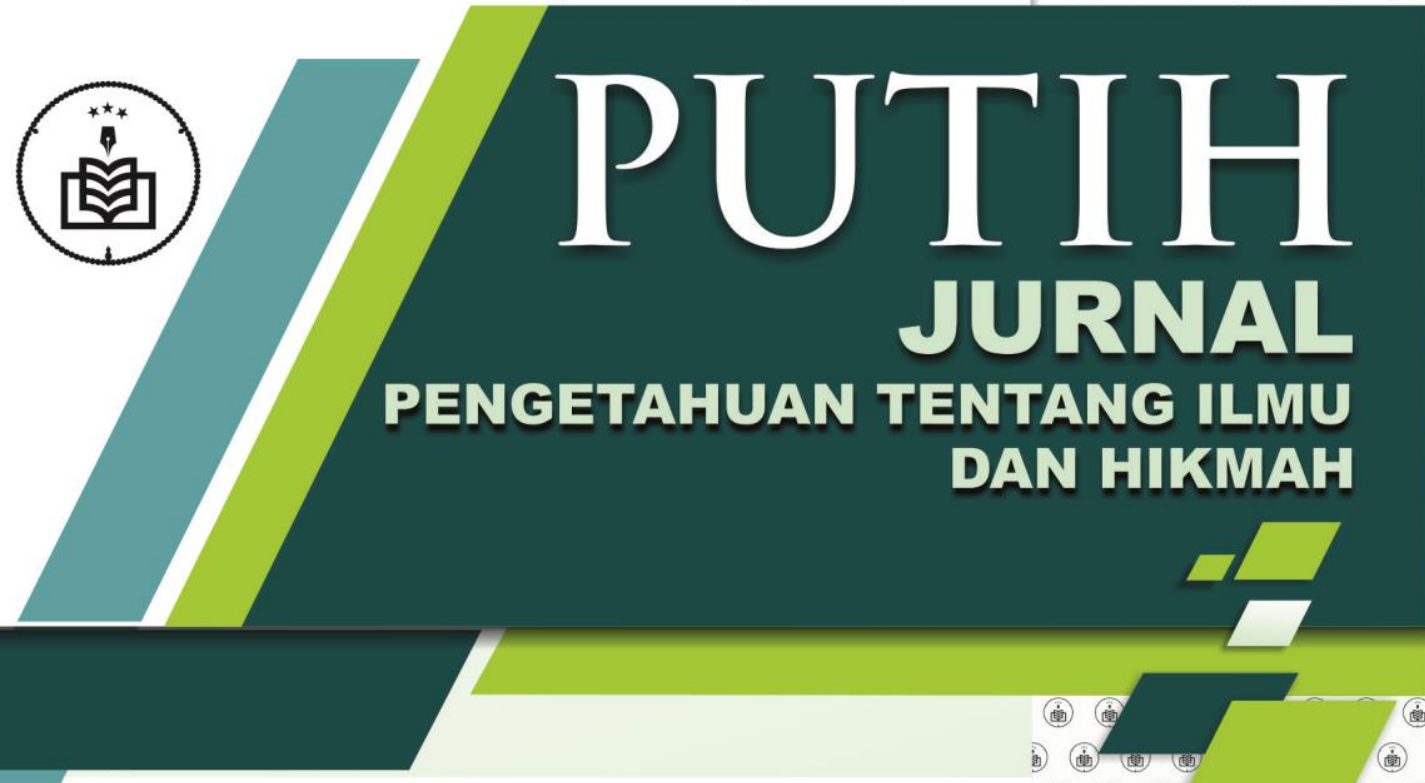

\section{HAKIKAT DOA}

Muhammad Husein Basofi 1-22

- MANAQIB SYEIKH ABDUL QADIR SEBAGAI MEDIA SULUK Durrotun Hasanah 23-42

- RELASI ANTARA AKAL DENGAN HATI PERSPEKTIF KH. ACHMAD ASRORI AL-ISHAQY Irwanto 43-64

- RELEVANSI AJARAN BUDHA DAN TASAWUF Mohammad Arista 65-100

- TERAPI SPIRITUAL MELALUI TAZKIYAH AL-QALB PERSPEKTIF ULAMA SHUFIYYAH

Anas Fajriansyah 101-122 (19i) (1) (19)

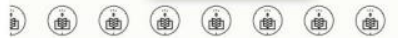

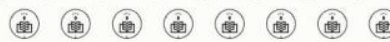

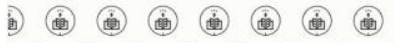

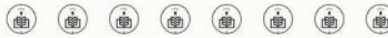

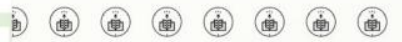

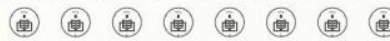

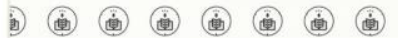

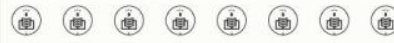
ib) (iii) (iii) (ii) (ii) (iii) (iii) (iit)

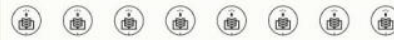

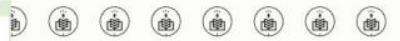

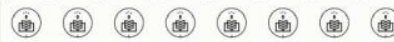

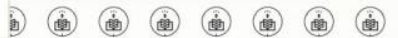

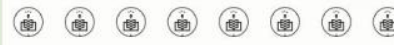

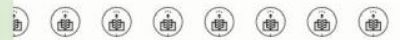

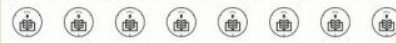

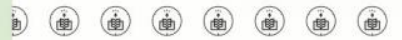

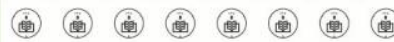
diterbitkan :

MA'HAD ALY

PONDOK PESANTREN ASSALAFI AL FITHRAH Surabaya 2017

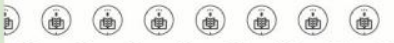

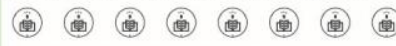
ib) (ii) (ii) (ii) (ii) (ii) (ii) (iii)

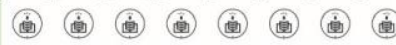
ib) (ii) (iii) (ii) (ii) (ii) (ii) (ii)

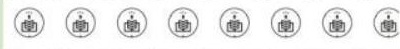

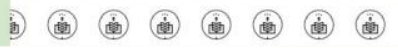




\section{REDAKTUR PUTIH \\ JURNAL PENGETAHUAN TENTANG ILMU DAN HIKMAH}

Ijin terbit

SK. Mudir Ma'had Aly No. 18/MAy-PAF/II/2017/SK

PENGARAH

Muhammad Musyafa'

Abdur Rosyid

Ahmad Syathori

Fathur Rozi

PIMPINAN REDAKSI

Fathul Haris

DEWAN EDITOR

Achmad Imam Bashori

ANGGOTA

Mustaqim

Samsul Arifin

Abdul Hadi

Alamat Penyunting dan Surat Menyurat :

Jl. Kedinding Lor 99 Surabaya

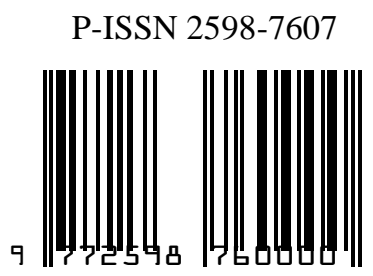

E-ISSN: 2622-223X

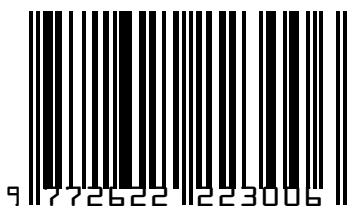

diterbitkan

MA'HAD ALY

PONDOK PESANTREN ASSALAFI AL FITHRAH

Surabaya 


\section{DAFTAR ISI}

DAFTAR ISI

— PEDOMAN TRANSLITERASI

ם HAKIKAT DOA

Muhammad Husein Basofi 1-22

— MANAQIB SYEIKH ABDUL QADIR SEBAGAI MEDIA SULUK

Durrotun Hasanah 23-42

RELASI ANTARA AKAL DENGAN HATI PERSPEKTIF KH. ACHMAD ASRORI AL-ISHAQY

Irwanto 43-64

- RELEVANSI AJARAN BUDHA DAN TASAWUF Mohammad Arista 65-100

TERAPI SPIRITUAL MELALUI TAZKIYAH AL-QALB PERSPEKTIF ULAMA SHUFIYYAH

Anas Fajriansyah 101-122 


\section{PEDOMAN TRANSLITERASI}

Berikut ini adalah skema transliterasi Arab-Indonesia yang ditetapkan dalam penulisan jurnal ini:

\begin{tabular}{|c|c|c|c|c|}
\hline $\mathrm{NO}$ & ARAB & INDONESIA & ARAB & INDONESIA \\
\hline 1 & 1 & 6 & b & t\} \\
\hline 2 & ب & B & ظ & $\mathrm{Z}\{$ \\
\hline 3 & ت & $\mathrm{T}$ & $\varepsilon$ & 6 \\
\hline 4 & ث & $\mathrm{Th}$ & $\dot{\varepsilon}$ & gh \\
\hline 5 & ج & $\mathrm{J}$ & ف & $\mathrm{F}$ \\
\hline 6 & $\tau$ & $\mathrm{h}\{$ & ق & Q \\
\hline 7 & $\dot{\tau}$ & $\mathrm{Kh}$ & 5) & $\mathrm{K}$ \\
\hline 8 & د & D & J & $\mathrm{L}$ \\
\hline 9 & j & $\mathrm{Dh}$ & r & $\mathrm{M}$ \\
\hline 10 & $\jmath$ & $\mathrm{R}$ & ن & $\mathrm{N}$ \\
\hline 11 & j & $\mathrm{Z}$ & 9 & W \\
\hline 12 & س - ل س & $S$ & a & $\mathrm{H}$ \\
\hline 13 & ش & $\mathrm{Sh}$ & $s$ & , \\
\hline 14 & ص & $s\{$ & ي & $\mathrm{y}$ \\
\hline 15 & ض & $d\{$ & & \\
\hline
\end{tabular}

Untuk menunjukkan bunyi hidup panjang (madd) dengan cara menuliskan coretan horizontal di atas huruf a, i>dan $u>($ ) $116)$. 


\title{
RELASI ANTARA AKAL DENGAN HATI PERSPEKTIF KH. ACHMAD ASRORI AL-ISHAQY
}

\author{
Irwanto \\ Email: Irwanto0012@gmail.com \\ Ma'had Aly Al-Fithrah Surabaya
}

\begin{abstract}
ABSTRAK
Manusia merupakan makhluk yang diciptakan oleh Allah SWT dengan keadaan yang paling bagus dan sempurna, dibandingkan makhluk lainnya baik malaikat, jin, ataupun binatang. Manusia diberi keistimewaan berupa akal yang mampu menuntun setiap tingkah lakunya dalam mengerjakan sesuatu. Sehingga manusia mengerti dan mengetahui mana yang baik dan mana yang buruk. Dan dengan akal-lah yang mampu membedakan kedudukan apakah lebih tinggi dari malaikat, atau malah lebih rendah dari pada hewan. Manusia yang mampu mengalahkan syahwatnya dan meluruskan akal ke jalan yang benar, maka derajatnya lebih tinggi dari malaikat. Sebaliknya, manusia yang menuruti hawa nafsunya tanpa menggunakan akalnya dengan benar, maka derajatnya lebih rendah dari pada hewan. Selain akal, manusia juga dikarunia oleh Allah SWT berupa hati, dimana keadaan manusia mampu merasakan keagungan sang penciptanya. Dimana hati-lah yang mampu mengendalikan akal dengan jalan yang lurus. KH. Achmad Asrori menjelaskan dalam kitabnya bahwa ketika manusia dapat memusatkan pikirannya (akalnya) dan hatinya dalam menghamba kepada Allah SWT maka orang tersebut mampu bermakrifat kepada Allah SWT. Dalam artian seorang hamba mampu merasakan getaran-getaran sifat-sifat Allah SWT dalam dirinya. Bahkan sifat-sifat-Nya pun mampu merasuk ke dalam setiap prilakunya. Dalam hal ini Beliau lebih fanatik menukil dari Imam Ghozali selaku Imam Hujjatul Islam, dan juga para tokoh-tokoh tasawuf terkemuka.
\end{abstract}

Keyword: Akal, Hati, KH. Achmad Asrori

Jurnal Putih Vol. II No. 1, 2017| 43 


\section{PENDAHULUAN}

Sesungguhnya Allah SWT telah memberikan anugerah kepada manusia barbagai keistimewaan yang tidak terdapat pada makhluk hidup lainnya meskipun itu pada malaikat. Manusia diciptakan di muka bumi ini dalam bentuk yang paling sempurna. Allah SWT memberikan petunjuk berupa kitab-kitab samawi melalui para Nabi dan Rasul-Nya untuk dijadikan pegangan hidupnya. Allah SWT menganugerahkan akal pikiran kepada manusia sebagai kunci untuk memperoleh petunjuk terhadap segala sesuatu. ${ }^{71} \mathrm{Hal}$ inilah yang membedakan manusia dengan makhluk lainnya, yakni akal yang dimiliki manusia mampu menuntun dan mengarahkan manusia terhadap sesuatu yang baik dan mana sesuatu yang buruk.

Pada dasarnya dalam diri seseorang terdapat dua potensi yang unggul, yakni potensi baik dan buruk. Dimana dari keduanya tergantung pada akal dan hati yang digunakannya dalam melakukan segala hal. Apabila manusia dalam keadaan baik jasmani dan ruhaninya maka secara keseluruhan prilaku manusia itu baik pula. Hal ini berdasarkan orang tersebut mampu menggunakan akal dan hatinya dengan benar. Sebaliknya seandainya manusia itu dalam keadaan yang buruk jasmani dan ruhaninya maka secara tidak langsung prilakunya banyak melakukan keburukan. Hal ini karena akal sehatnya tidak digunakan lagi, sehingga membuat hatinya semakin padam sedikit demi sedikit.

\section{TERMINOLOGI AKAL DAN HATI}

\section{Terminologi Akal}

Akal secara bahasa merupakan ikatan, batasan, atau menahan, bisa juga diartikan sebagai daya pikir yang dimiliki manusia. Sedangkan secara istilah kata Akal merupakan lawan kata dari jahl (kebodohan atau ketidaktahuan) dimana akal mempunyai beberapa makna, yaitu sebagai berikut:

a. Kemampuan untuk mengetahui sesuatu.

b. Kemampuan membedakan kebaikan dan keburukan yang niscaya juga dapat digunakan untuk mengetahui hal-ihwal yang

\footnotetext{
${ }^{71}$ Anwar Sutoyo, Bimbingan dan Konseling Islami (Teori dan Praktik), (Semarang: Cipta Prima Nusantara, 2007) 66.
} 
mengakibatkannya dan sarana-sarana yang dapat mencegah terjadinya masing-masing dari keduanya.

c. Kemampuan dan keadaan (haalah) dalam jiwa manusia yang mengajak kepada kebaikan dan keuntungan dan menjauhi kejelekan dan kerugian.

d. Kemampuan yang bisa mengatur perkara-perkara kehidupan manusia.

e. Akal juga dapat dipakai untuk menyebut tingkat kesiapan dan potensialitas jiwa dalam menerima konsep-konsep universal. AnNafs An-Nathiqoh (jiwa rasional yang dipergunakan unutk menalar) yang membedakan manusia dengan binatang dan makhluk lainnya.

f. Dalam bahasa filsafat, akal merujuk kepada substansi azali yang tidak bersentuhan dengan alam material, baik secara esensial (Dzati) maupun (fi'li). ${ }^{72}$

Jadi, dapat disimpulkan bahwa akal adalah makhluk yang mengarahkan jiwa dan membuatnya memilih beberapa alternatife memberitahu mana yang baik dan mana yang buruk serta mana yang halal dan mana yang haram. Selain itu, Imam Hujjatul Islam wal Muslimin Al-Ghozali r.a juga mendefinisikan akal sebagai sebuah sumber dan muara serta landasan ilmu. Ilmu yang mengalir dari akal laksana mengalirnya buah dari pohon, cahaya dari matahari serta penglihatan dari mata. Sudah barang tentu sesuatu yang menjadi perantara kebahagiaan dan keberuntungan dunia dan akhirat itu adalah mulia.

Antara akal dan ilmu dalam dunia pengetahuan terdapat perdebatan yang panjang mengenai mana yang lebih utama. Sebagian ulama' ada yang mengatakan bahwa akal lebih mulia dari pada ilmu, sebab akal merupakan sumber dan dasar ilmu. Sebagian ulama' lainnya berpendapat bahwa ilmu lebih utama dari pada akal, karena ketergantungan akal terhadap ilmu dan karena Allah SWT hanya boleh disifati dengan ilmu bukan dengan akal. Oleh karena itu, boleh mensifati Allah SWT dengan ilmu dan tidak boleh mensifati-Nya

\footnotetext{
${ }^{72}$ Ahmad Syauqi Ibrahim, Misteri Potensi Ghaib Manusia (Jakarta: Qisthi Press, 2012), 250 .
} 
dengan akal. Pembahasan mengenai hal ini sangat panjang, maka dicukupkan disini jawaban atas pertanyaan itu. Dan hanya Allah SWT-lah yang Maha Tahu. ${ }^{73}$

Hal ini sesuai dengan Al-Imam Al Hafidz Jalaluddin AsSuyuthi yang ditanyai mengenai apakah akal lebih utama dari pada ilmu, ataupun sebaliknya. Beliaupun menjawab "ini adalah masalah yang diperdebatkan oleh para ulama', namun mereka lebih mengutamakan ilmu karena Allah SWT disifati dengan ilmu tidak disifati dengan akal. Dan sesuatu yang bisa diterapkan sebagai sifat Nya Allah SWT itu lebih utama dari pada sesuatu yang tidak bisa diterapkan sebagai sifat-Nya. Meskipun ilmu Allah SWT itu Qodim (terdahulu), sedangkan ilmu kita adalah sesuatu hal yang baru (Hadits). Sebab Allah SWT sama sekali tidak boleh disifati dengan akal, dan akal juga tidak boleh dianggap sesuatu yang terdahulu. ${ }^{74}$

Allah SWT memberi nama akal dengan sebutan nur-cahaya, sebagaimana dalam firman-Nya:

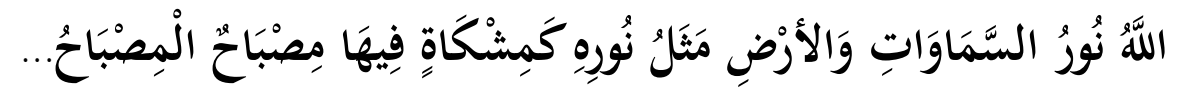

"Allah SWT (pemberi) cahaya (kepada) langit dan bumi. Perumpamaan cahaya Allah SWT adalah seperti sebuah lubang yang tidak tembus, yang di dalamnya ada pelita besar" 75

Dan Allah SWT memberi nama ilmu yang diperoleh dan dihasilkan dari akal dengan nama ruh, wahyu, dan hayat (hidup dan kehidupan). Allah SWT berfirman:

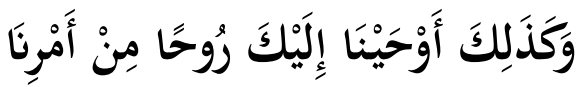

\footnotetext{
${ }^{73}$ KH. Achmad Asrori r.a, Untaian Mutiara dalam Ikatan Hati dan Jalinan Rohani (Surabaya, Al-Wafa: 2015) , J. 1, 287.

${ }^{74}$ Ibid, 288.

${ }^{75}$ Penerbit JABAL J1. Desa Cipadung No. 47 Cibiru Bandung (Qur'an Surah An-Nur: 35), 354.
} 
"Dan demikianlah Kami wahyukan kepadamu wahyu (Al Quran) dengan perintah Kami". 76

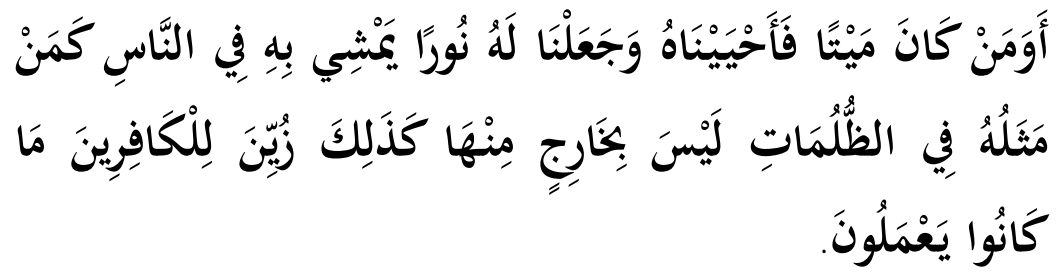

"Dan Apakah orang yang sudah mati ${ }^{77}$ kemudian dia Kami hidupkan dan Kami berikan kepadanya cahaya yang terang, yang dengan cahaya itu dia dapat berjalan di tengah-tengah masyarakat manusia, serupa dengan orang yang keadaannya berada dalam gelap gulita yang sekali-kali tidak dapat keluar dari padanya? Demikianlah Kami jadikan orang yang kafir itu memandang baik apa yang telah mereka kerjakan". (QS. Al-An'aam: 122).

Pada lafad "An nuur dan adl dlulmah" yakni "cahaya dan kegelapan" mempunyai makna yang bermaksud ilmu dan kebodohan, seperti firman-Nya dalam surah al-Baqarah ayat 207 yang artinya adalah sebagai berikut:

"Allah SWT adalah pelindung bagi orang-orang yang beriman, Dia mengeluarkan mereka dari kegelapan menuju kepada cahaya”. (QS. Al-Baqarah: 207).

Diriwayatkan dari Sayyidatuna "Aisyah -radhia Allah hu 'anHha- bahwa Rasulullah Saw bersabda "Ciptaan Allah Swt yang pertama kali adalah akal, lalu Allah Swt berfirman: "Menghadaplah! . . . "maka menghadaplah akal. Allah Swt berfirman lagi: "Berpalinglah! ... maka akal pun berpaling. Allah Swt lalu berfirman: "Demi kemuliaan dan keagungan-Ku, tidaklah Aku menciptakan

${ }^{76}$ Ibid, 483.

${ }^{77}$ Maksudnya adalah orang yang telah mati hatinya, yakni orang-orang kafir dan lain sebagainya. 
makhluk yang lebih mulia dari pada kamu, dengan Aku mengenggam, denganmu Aku memberi, denganmu Aku memberi pahala, dan denganmu Aku menyiksa. ${ }^{78}$

\section{Macam-macam Akal}

Menurut sebagian ulama' suffah radhiallahu 'anhHum menerangkan bahwa akal terbagi menjadi lima macam:

a. Ghorizy adalah kekuatan yang tertanam dan tertancap dalam hati yang disiapkan dan disiagakan guna untuk mengetahui ilmu pengetahuan yang memerlukan pemikiran.

b. Kasby adalah sesuatu yang diusahakan dan diupayakan serta diperoleh seseorang dari perkumpulan dan pergaulan dengan orang-orang yang berakal sehat.

c. 'Atho'i adalah sesuatu yang dianugerahkan oleh Allah Swt Swt kepada orang-orang yang beriman, agar mendapatkan hidayahpetujuk untuk beriman.

d. Aqluz Zuhhad adalah sesuatu yang menyebabkan zuhud (tidak adanya ketergantungan dan ketersandaran terhadap dunia dan seisinya).

e. Syarofy adalah akal yang dimiliki oleh Baginda Habibillah Rasulillah Muhammad Saw dan itulah akal yang paling mulia dan juga luhur.

Sayyidina Abu Abdillah WaHhbin bin MunabbiHh Ash Shun'any Adz Dzimary r.a berkata: "Saya membaca tujuh puluh satu kitab, dan saya mendapatkan semuanya berisi "Sesungguhnya akal

${ }^{78}$ HR. Thobrony dalam Al-Ausath dari Abi Umamah, dan Abu Nua'im Al-Ashbihany dengan dua sanad yang dho'if. Imam Syakhowi dan As-Suyuthy berkata: "Hadist ini juga diriwayatkan oleh ibnu ahmad dalam zawaaiduz Zuhdi dari Sayyidina Hasan alBashri ra. secara marfu'. Hadist ini dinilai mursal dengan sanad yang baik. Dan diriwayatkan Ibnu Muhbir tidak mengharuskan adanya Hadist ini sebagai Hadist palsu, apalagi hadist tersebut telah diriwayatkan oleh para Imam dengan tanpa sanad Ibnu Muhbir, sehingga Hadits tersebut bukan Hadits palsu". Al Hafidz Ibnu Hajar berkata: "Hadits yang datang dari Rosulullah Saw yang menjelaskan makhluk yang pertama kali diciptakan adalah Hadits: "Makhluk yang pertama kali diciptakan adalah qolam", Hadits ini lebih kuat dari pada Hadits tentang akal. Kasyful Khofa'. 
yang diberikan oleh Allah SWT kepada semua manusia sejak awal wujudnya dunia hingga dunia ini sirna, tidaklah sebanding dengan akal Baginda Habibillah Rasulillah SAW. Perumpamaannya laksana sebutir pasir dibanding dengan semua pasir-pasir yang ada dijagat raya. Dan Beliaulah orang yang akalnya paling unggul dan pendapatnya paling utama".

Imam Abu Abdillah Muhammad bin Abdurrahman alBukhory yang bergelar Azzahid Al 'Alaa'y r.a dalam tafsirnya meriwayatkan dari Sayyiduna Ibnu Abbas -radhiAllahhu 'anHhuma-: "Allah SWT menciptakan akal atas seribu bagian, yang sembilan ratus sembilan puluh sembilan bagian diberikan kepada Baginda Habibillah Rasulillah Muhammad SAW dan sisanya yang satu bagian diperuntukan kepada semua makhluk, satu bagian dibagi menjadi sepuluh bagian, sembilan bagian diberikan kepada para Nabi SAW dan sisanya yang satu bagian untuk semua makhluk. Yang satu bagian tersebut dibagi menjadi sepuluh bagian, yang sembilan bagian untuk kaum laki-laki dan satu bagian untuk kaum perempuan.

Imam Al Habib Al 'Arif Billah Abdullah bin Muhsin Al Athos ra. berkata: Akal itu terbagi menjadi empat golongan:

a. Qusyur (kulit ular): yaitu orang-orang awam.

b. Al Lubbu (sari pati): yaitu akal ulil absor (orang-orang yang mempunyai pandangan lahir).

c. Lubbul Lubbi (intisarinya sari pati): yaitu akal Ulil Albab (orangorang yang mempunyai pandangan lahir dan batin).

d. DuHhul Lubbi (akal yang menempati posisinya sari dari intisarinya sari pati) yaitu akal yang diberikan kepada Baginda Habibillah Rasulillah Muhammad Saw.

Sebagian ulama' sufiyyah -radhiAllahu 'anh- bekata:

"Bahwa Allah SWT menciptakan makhluk menjadi tiga golongan:

a. Golongan makhluk yang mempunyai syahwat tanpa akal, yaitu binatang dan sejenisnya

b. Golongan makhluk yang mempunyai akal tanpa syahwat, yaitu malaikat.

c. Golongan makhluk yang mempunyai kedua-duanya yaitu akal dan syahwat, adalah anak-cucu Adam. 
Barang siapa yang akalnya mengalahkan syahwatnya, maka ia lebih mulia dari pada malaikat, sebab ia memerangi hawa-nafsunya dengan menahan syahwat dan mengarahkan serta membawanya menuju keta'atan. Dan barang siapa yang syahwatnya mengalahkan akalnya, maka ia lebih buruk dari pada binatang ternak

\section{TERMINOLOGI HATI}

Kata hati dalam bahasa arab dikenal dengan qalb yang mempunyai arti hati. Penggunaan istilah "hati" ini terkesan tumpang tindih dengan istilah jantung, karena dalam bahasa Inggris istilah "qalb" lazimnya diterjemahkan dengan (jantung) dan bukannya liver (hati).

Dalam Mu'jam al-Wasiith disebutkan bahwa salah satu makna qalb adalah jantung yang menjadi pusat peredaran darah yang terletak di dada sebelah kiri. Ibnu Manzur dalam Lisaan al-'Arab menyebut qalb sebagai segumpal daging (mudghah) yang menggantung pada sesuatu. Makna ini berkaitan dengan hadis Nabi SAW tentang mudghah yang menunjuk pada sesuatu di dalam dada (hati/qalb). Qalb juga memiliki arti inti $(l u b b)$ dari segala sesuatu, seperti sabda Nabi SAW, "Setiap sesuatu ada qalb (inti) nya dan inti al-Qur'an adalah Surah Yasin”. Sepertinya pengertian demikian juga dikemukakan oleh Ibnu Qayyim al-Jauziyah yang menggunakan kata qalb untuk menyebut jantung sesuatu, seperti Yasin sebagai jantung al-Qur 'an. Hal itu menunjukkan bahwa penggunaan kata qalb pada diri manusia lebih sering menunjukkan jantung, inti dan pusat diri manusia. ${ }^{80}$

Dinukil dari Imam Al-Ghozali bahwa Istilah qalb itu mengandung dua pengertian, yakni materi dan spiritual. Pengertian materi adalah organ tubuh jantung yang berbentuk kerucut yang terletak di sebelah kiri rongga dada. Dalam pengertian ini, hewan pun juga dikatakan mempunyai qalb. Adapun pengertian spiritual yaitu lutf rabbaaniyyuun ruuhaaniyyuun atau hakikat manusia yang halus yang mengenali, mengetahui, yang diajak bicara, yang dituntut, diberi pahala, dan disiksa.

\footnotetext{
${ }^{79}$ Al-Ghazali, Terjemah Mi'raaj Al-Saalikiin (Kairo: Silsilah Al-Tsaqaafah AlIslaamiyyah, 1964) 16.

${ }^{80}$ Majma' al-Lughah al- 'Arabiyyah, Mu'jam al-Washith, (Saudi Arabia: Daar Ihyaa' alTutaats al-'Arabiy, 1983), 753.
} 
Dalam pengertian yang terakhir ini, al-Ghazali menyamakannya dengan definisi nafs dan akal. Ini artinya, hanya manusia yang memilikinya, hewan tidak. ${ }^{81}$

Meskipun qalb bukanlah jantung atau hati dalam arti fisik, namun qalb mempunyai hubungan yang sangat erat dengan kedua organ itu bahkan dengan seluruh anggota badan. Salah satu bukti konkret dalam hubungan qalb dengan jantung misalnya, ketika jiwa sedang cemas atau khawatir maka akan bertambah cepat pula detak jantung. Itulah sebabnya kita sering mendengar ungkapan bahwa hati di dalam dada, dan hati adalah tempat iman sebagaimana hadis Nabi SAW yang mengatakan bahwa iman letaknya di hati, sambil menunjuk dada beliau. Penggunaan kiasan semacam inilah yang menurut al-Ghazali kadang-kadang dengan jalan tidak langsung (kinaayah), dan yang pasti karena adanya hubungan khusus antara yang halus dengan anggota tubuh. Pada keterangannya yang lain, hubungan ini ibarat hubungan raja dengan pasukannya, pemilik alat dengan alatnya, atau orang yang bertempat dengan tempatnya. Gambaran hubungan antara qalb dan jantung ini merupakan analogi yang dipakai al-Ghazali untuk menegaskan bahwa qalb-lah yang menyatu dan memutuskan pergerakan anggota badan menjadi sebuah perbuatan. ${ }^{82}$

Makna qalb dari sisi spiritualitas berkaitan erat dengan roh manusia yang membawa amanah dari Allah SWT, yang dihiasi dengan ilmu pengetahuan-Nya, pengetahuan yang didasari dengan fitrah dasarnya, dan roh yang selalu mengumandangkan keesaan Allah SWT. Dengan kelembutan hati, seseorang bisa mengetahui dan memahami dirinya. Dan pada saat itu, seorang manusia dapat mengerti hakikat jiwanya, dan dengan mengerti hakikat jiwanya ia akan mendapatkan petunjuk untuk mengetahui dan mengerti Allah SWT. Ia mampu menyaksikan sirrirahasia ke-Esaan Dzat Allah SWT, dan bekas-bekas, Sifat-sifat, dan Asma Allah pada semua yang tampak akan tersingkap, sebagaimana yang terkandung dalam sabda Baginda Habibillah Rasulillah Muhammad SAW: "Barang siapa mengetahui dan mengerti jiwanya, maka ia akan mengetahui dan mengerti Tuhannya", yakni barang siapa nur-cahaya

${ }^{81}$ Al-Ghazali, Ihyaa' 'Uluum al-Diin, J. III, 6.
${ }^{82}$ Ibid, 8. 
jiwanya tersingkap, maka akan tersingkap pula nur-cahaya Tuhannya". Karena jiwa -yakni ruh seseorang- akan mencakup sirri-rahasia yang ada dalam hadhroh ketuhanan yang suci namanya, dengan cakupan yang bersifat bawaan dan sesuai dengan wujud dalam kenyataan. ${ }^{83}$

Barangkali hal ini -menurut Kh. Achmad asrori r.a- dinamakan dengan sebutan Wuquf Qolbi. Wuquf Qolbi adalah jalan menuju Allah SWT yang paling dekat setelah jalan muroqobah. Dengan cara menghadapkan mata hati pada hakikat ruh insan. Karena ruh insan pada awalnya mempunyai keterkaitan dengan badan (akal) dari arah hati. Setelah itu, ruh akan berinteraksi dalam badan dengan perantara hati. Dan barang siapa menghadapkan mata hatinya ke hakikat ruh, maka ia akan melihat hakikat ruhnya dan mengerti jiwanya, serta nur-cahaya ruh dan kesempurnaan jiwanya akan tersingkap baginya. ${ }^{84}$

Hadhrotusy Syaikh -KH. Achmad Asrori r.a- berkata: "Dalam hadits dijelaskan: "ingatlah ! . . Sesungguhnya setiap penguasa memiliki bumi larangan. Ingatlah ! . . . sesungguhnya bumi larangan Allah Swt adalah hal-hal yang diharamkan-Nya. Ingatlah ! . . sesungguhnya di dalam tubuh terdapat segumpal daging, ketika segumpal daging tersebut baik, maka jasad pun akan menjadi baik, dan jika rusak, maka jasad pun akan menjadi rusak. Ingatlah ! . . . segumpal daging tersebut adalah hati". 85

Secara khusus hati diungkap sebab kebaikan dan kebrobrokan jasad mengikuti kebaikan dan kebrobrokan hati, karena semua gerak-gerik badan dan keinginan jiwa dimulai dari gerak-gerik dan keinginan hati. Jika hatinya baik maka gerak-gerik dan keinginannya akan baik demikian juga sebaliknya jika hatinya rusak maka gerak-gerik dan keinginannya akan rusak pula. Sehingga seorang hamba tidak akan mampu menutupi dan membohongi apa yang terlintas di dalam hatinya.

Sifat hati adalah berubah-rubah, berpindah-pindah, atau berbolakbalik. Sama halnya dengan jantung yang mempunyai sifat selalu berdetak dan naik-turun, bolak-balik memompa darah. Sedangkan secara psikis

\footnotetext{
${ }^{83}$ KH. Muhammad Utsman bin Nadi Al Ishaqy r.a, Nuqthoh dalam Hakikat Makna Robithoh (Surabaya, Al-Wafa, 2010) 134-148. Cet-pertama

${ }^{84}$ Ibid, 133.

${ }^{85}$ HR. Syaikhoni dari sayyidina Nu'man bin Basyir r.a.
} 
kalbu -hati/jantung- berarti bolak-balik antara iya dan tidak, kuat dan lemah, yakin dan ragu, tenang dan gundah, atau sejenisnya. ${ }^{86}$ Dari keterangan makna serta kaitannya dengan fisik dan psikis qalb di atas, menunjukkan bahwa qalb/hati memang mempunyai sifat dominan yang menjadi karakteristiknya, yaitu selalu berubah-ubah yang selanjutnya memberi pengaruh pada kejiwaan manusia yang juga berubah-ubah.

Sesungguhnya Allah SWT memberikan keistimewaan terhadap manusia berupa hati, dimana hati adalah elemen terpenting diantara elemen-elemen lainnya baik tubuh maupun fisik. Oleh karena itu, Allah SWT menciptakan hati kepada manusia bukan digunakan untuk sia-sia, melainkan harus digunakan untuk bisa mendekati Allah SWT. ${ }^{87}$ Rasulullah SAW bersabda: "Sesungguhnya hatiku selalu bergejolak (tertutupi atau terliputi oleh nur-cahaya), dan aku senantiasa memohon ampun kepada Allah SWT seratus kali dalam sehari semalam". 88

Dalam hal ini, KH. Achmad Asrori r.a terkait hadist diatas Beliau ikut berkata: "Para ulama' berbeda pendapat dalam mengartikan ghoin (gejolak atau terliputinya hati Rasulullah SAW): ${ }^{89}$

Pertama: Imam Qodli 'Iyadh berkata: "Yang dimaksud dengan Ghoin adalah lemah semangat dalam berdzikir, padahal semestinya Rasulullah SAW harus senantiasa berdzikir. Maka, ketika muncul ketidaksemangatan Rasulullah SAW menganggapnya sebagai dosa, oleh karena itu Beliau SAW ber-istighfar.

Kedua: Ghoin adalah bisikan yang timbul dalam hati atau adanya isyarat akan terjadinya sesuatu dalam hati seorang salik yang telah mencapai derajat yang tinggi dan kedudukan yang dekat disisi Allah SWT dengan menganggap baik sebuah prilaku batin, akan tetapi ia lupa untuk melihat sesuatu yang lebih utama. Karena pekerjaan apapun sekalipun secara hukum syara' dinisbatkan kepada manusia. Namun, pada hakikatnya berada diluar jangkauan pengetahuannya.

\footnotetext{
${ }^{86}$ Yadi Purwanto, Psikologi Kepribadian..., 151.

${ }^{87}$ Al-Ghozali:1998

${ }^{88}$ HR. Imam Ahmad bin Hambal, Muslim, Abu Daud, Nasa'i, Ibnu Majah, Thobroni, dan Baihaqi dari Aghor Al Mazani. KH. Achmad Asrori, Mutiara Hikmah dalam Ma'rifat Kehadirat Allah Swt (Surabaya: Al-Wafa, 2010) 44.

${ }^{89}$ KH. Achmad Asrori, Untaian Mutiara dalam Ikatan Hati dan Jalinan Rohani (Surabaya, Al-Wafa, 2015) 68-69.
} 
Ketiga: Ghoin adalah perasaan tenang yang menutupi hati, sedangkan istighfar dimaksudkan untuk menampakkan sikap dan sifat penghambaan diri terhadap Allah SWT dan bersyukur atas semua nikmat-Nya.

Keempat: Ghoin adalah perasaan takut kepada Allah SWT sekaligus perasaan mengagungkan atas kebersaran-Nya yang menyelimuti hati seseorang. Oleh karenanya, kemudian ia bersyukur kepada Allah SWT dan menetapi sifat dan rasa kehambaan. Seperti yang disabdakan oleh Rasulullah SAW: "Tidak bolehkah aku menjadi hamba yang senantiasa bersyukur kepada-Nya?..."

Kelima: Rasulullah SAW bersabda bahwa hatinya selalu tertutupi, tujuannya Adalah dalam rangka memberikan pelajaran kepada umatnya, meskipun mereka yang sudah mencapai tingkat kesempurnaan. Karena mayoritas manusia melakukan kesalahan dan tidak lepas dari berbuat ceroboh (sembrono-jawa) terhadap hak-hak Allah SWT seperti yang disinyalir oleh Rasulullah SAW dalam haditsnya:

"Maha Suci Engkau, kami belum bisa menyembah-Mu dengan menyembah (beribadah) yang sebenarnya".

Keenam: Setiap kali Rasulullah SAW mengingat umatnya dan apa yang terjadi pada mereka Beliau memohonkan ampunan untuk mereka.

Dan kemudian Beliau (KH. Achmad Asrori) berkata: "Menurut saya inilah jawaban paling sesuai dan makna yang paling bagus dalam hal menjaga adab terhadap Rasulullah SAW.

Jadi, ketika manusia mampu menggunakan akalnya dengan benar dan menjaga hatinya dalam setiap langkahnya maka hasilnya seorang tersebut memiliki adab yang bagus terhadap sesama makhluk atau kepada Tuhannya (Allah SWT). Bahkan keadaan yang seperti ini justru membuat seorang hamba naik derajatnya disisi Allah SWT, gerakan ruhani dan hatinya pun lebih cepat dari pada jiwanya.

\section{FUNGSI AKAL DAN HATI}

Tujuan diciptakannya manusia tiada lain adalah untuk menyembah Tuhan. Hal ini membutuhkan konsekuensi adanya iman kepada-Nya. Iman hanya bisa datang dengan adanya hidayah dan kesiapan hati menerima hidayah. Bagaimana hati manusia akan sanggup dan siap 
menerima hidayah sedangkan dia tidak mengenal Tuhan. Maka dalam proses mengenalkan Tuhan kepada manusia, diutuslah para rasul untuk menyampaikan wahyu Tuhan kepada manusia. Namun selain itu, Allah SWT juga membekali manusia akal yang berpotensi membenarkan wahyu dan hati yang berpotensi untuk mengenal-Nya ( $m a^{\prime}$ 'rifah) ${ }^{90}$

Dalam hal menemukan kebenaran inilah terletak fungsi jiwa manusia yang diwakili kognisi spiritual yang bernama hati, karena memang inilah maksud diciptakannya hati bagi manusia, yaitu untuk mengetahui dan mengenal Allah SWT dengan cara merasakan dan menghayati serta menfokuskan pusat pikiran dan menenangkan hati pada satu tujuan, yakni Allah SWT. ${ }^{91}$ Kalau dilihat dari fungsi ini, posisi antara hati dan akal adalah sama, yaitu fakultas yang bisa mengetahui.

Di antara fungsi hati yang lain adalah diberi kemampuan melihat secara batin, yang menurut al-Ghazali juga disebut penglihatan. Kalau tidak mampu melihat maka dinamakan buta (buta mata hati). Sebutan ini bisa menjadi alasan adanya ayat-ayat tentang butanya mata hati, hati tidak memahami, hati tidak berakal, atau hati yang mati. Karena hati sendiri juga substansi yang berakal, hati adalah akal, akal adalah hati. ${ }^{92}$

Dalam perspektif psikologi Islam, hati mempunyai fungsi-fungsi yang berkaitan dengan penyebutannya dalam al-Qur'an. Fungsi-fungsi tersebut di antaranya: ${ }^{93}$

1. Al-shadr, yaitu tempat perasaan was-was.

2. Al-qalb merupakan tempat iman.

3. Al-syaghaaf, yaitu tempat cinta.

4. Al-fu'ad, yiatu yang dapat memelihara kebenaran.

5. habat al-qalb, sebagai tempat cinta dan kebenaran

6. Al-suwaida', yaitu tempat ilmu dan agama.

7. Muhjat al-qalb, yang merupakan manifestasi sifat-sifat Allah Swt

8. Al-dhamiir, merupakan tempat merasa dan daya rekoleksi (alquwwah al-hafizah), dan

9. Al-sirr, sebagai bagian hati yang paling halus dan rahasia.

\footnotetext{
${ }^{90}$ Al-Ghazali, Ihyaa' 'Uluum al-Diin, J.z III, 7.

${ }^{91}$ Ibid, 10.

${ }^{2}$ Al-Ghazali, Ihyaa' 'Uluum al-Diin, J. V, 290-293.

${ }^{93}$ Baharudin, Paradigma Psikologi Islam..., 168.
} 
Menurut Baharudin, dalam hubungannya dengan fungsi akal, hati memiliki fungsi kongnisi, fungsi emosi, dan fungsi konasi. Fungsi kognisi menimbulkan daya cipta, seperti berpikir (al-fikr), memahami (al-figh), mengetahui (al-ilm), memperhatikan (dabara), mengingat (dzikr), dan melupakan (ghulf). Adapun fungsi emosi menimbulkan daya rasa, seperti tenang (thuma'ninah), sayang (ulfah), senang, santun, dan penuh kasih sayang (ra'fah warahmah), tunduk dan bergetar (wajilat), mengikat (ribaath), kasar (ghaliz\}), takut (khouf), dengki (ghill), berpaling (zaaiq), panas, sombong, dan kesal. Terakhir fungsi konasi yang menimbulkan daya karsa, seperti berusaha (kasb).

Melihat dari keterangan di atas dapat diambil kesimpulan, bahwa menurut al-Ghazali fungsi akal dan hati manusia yang paling utama adalah untuk menangkap kebenaran menuju satu tujuan hakiki manusia, yaitu mengenal dan mengetahui Allah SWT sehingga timbul-lah iman. Sedangkan hubungan antara akal dan hati sebagai dimensi psikis manusia, tidak saja yang memegang peran pengetahuan dan perbuatan manusia, tetapi sebagaimana disebutkan di dalam al-Qur'an juga berfungsi menghasilkan daya cipta, rasa, dan karsa. Akal dan hati adalah sama sebagai substansi yang mengetahui dan berakal, namun berbeda dalam kemampuan menangkap wilayah pengetahuan, di mana hati lebih luas dari akal.

\section{RELASI AKAL DAN HATI DALAM KEJIWAAN MANUSIA}

Dalam kontek kejiwaan, manusia dipengaruhi oleh dimensi psikis yang memiliki nilai dan kadar kemanusiaan yang bersumber pada dimensi jiwanya (nafs). Dengan artian walaupun manusia hanya terdiri dari substansi material (badan) dan imaterial (jiwa, roh, akal dan hati), namun sejatinya substansi material manusia hanyalah materi dasar yang mati, karena kehidupannya tergantung kepada adanya substansi lain, yakni nafs dan ruh. ${ }^{94}$

Kalau menelaah konsep nafs dalam al-Qur'an, dapatlah dipahami bahwa nafs adalah sisi psikis yang memiliki kekuatan ganda, yaitu al-

\footnotetext{
${ }^{94}$ Abu al-Husain Ahmad bin Faris bin Zakariya, Mu'jam al-Maqaayis fii al-Lughah, (Beirut: Daar al-Fikr, 1994), 672.
} 
ghadabiyyah dan al-syahwaniyyah. Prinsip kerja kedua daya ini adalah berusaha untuk mengejar kenikmatan dan mengumbar dorongandorongan agresif dan seksual, sehingga manusia yang hanya menuruti kedua daya ini tak ubahnya seperti binatang dalam hal orientasi hidup yang dia kejar, bahkan lebih hina. Oleh karena itu, dorongan ini dinamakan al-nafs al-hayawaaniyyah yang apabila tidak terkendali akan mengantarkan manusia bergaya hidup hedonis, seks bebas, materialistik, dan lain-lain. Gaya hidup seperti inilah yang dicela al-Qur'an bahwa ketika hawa nafsu menguasai manusia akan selalu mengarahkan kepada keburukan dan bencana. Namun apabila jiwa mampu mengendalikan kedua daya ini, maka kedua daya tadi akan berfungsi sebagai daya pelindung dan daya kehidupan, serta mendorong pemiliknya untuk memunculkan sisi kemanusiannya, menikmati hidup, dan berbuat kebaikan. Hal ini hanya akan terjadi apabila jiwa manusia mengedepankan sisi akal dan sisi hati atas nafsunya (hawa nafsu).

Akal dan hati merupakan dua unsur yang menentukan kadar dan nilai kejiwaan manusia, sebagai karakteristik manusia dan memberikan ciri khas dalam dimensi nafs. ${ }^{95}$ Sebagai dimensi psikis, akal dan hati juga memberikan ciri khas kepada dimensi al-nafs, al-ruuh, dan al-fithrah. Sebagai contohnya, makhluk yang hanya dikendalikan oleh nafs -dalam hal ini nafsu- maka ia adalah binatang. Sementara makhluk yang hanya dipengaruhi oleh al-ruuh dan al-fithrah adalah malaikat. Sedangkan manusia adalah gabungan fungsi dan kadar kebinatangan dan kemalaikatan yang memiliki warna kemanusiaan karena dirangkai dengan dimensi akal dan hati dalam susunan komposisi psikis manusia.

Senada dengan yang diatas, Hadrotus Sayikh Achmad Asrori r.a berkata: "Manusia merupakan golongan makhluk yang mempunyai akal dan syahwat. Dan barang siapa yang akalnya mampu mengalahkan syahwatnya, maka ia lebih mulia dari pada malaikat, sebab ia memerangi hawa-nafsunya dengan menahan syahwat dan mengarahkan dan membawanya menuju keta'atan. Dan sebaliknya, barang siapa

${ }^{95}$ Baharuddin, Ibid., 113-114. 
syahwatnya mengalahkan akalnya, maka ia lebih buruk dari pada binatang ternak". 96

Selanjutnya, al-Ghazali menjelaskan, bahwa badan adalah kendaraan bagi hati dengan bekal atau bahan bakarnya adalah yang didapat selama kehidupan di dunia, yaitu ilmu yg bermanfaat yang akan menghasilkan amal saleh. Karena badan adalah alat yang bisa rusak, maka menjadi kewajiban hati untuk menjaga badan dengan tiga cara, yaitu dengan makan, dengan menjaganya dari sebab-sebab kehancuran badan, dan dengan pengetahuan. Dalam masalah makan, diciptakanlah bagi hati dua tentara, yaitu batin dan dhohir. Yang batin berupa syahwat, dan yang dhohir adalah tangan dan anggota badan yang dibutuhkan saat makan. Dalam menjaga dari sebab kerusakan diciptakan pula dua tentara, yaitu batin dan dhohir. Yang batin ialah sifat marah, sementara yang dhohir adalah tangan dan kaki yang mengikuti kemauan sifat marah. Maka dalam hal ini seluruh anggota badan laksana senjata bagi qalb (jiwa). Selain itu juga diciptakan unsur pengetahuan dalam menjaga badan dari kehancuran. Pertama: batin, yaitu pengetahuan daya indrawi (penglihatan, pendengaran, penciuman, perasa, dan peraba) dan dhohir, yaitu alat panca indra. ${ }^{97}$

Dalam penjelasan selanjutnya di dalam kitab Kiimiyaa' alSa'aadah, al-Ghazali menggambarkan bahwa manusia (nafs) ibarat sebuah gambaran kota pemerintahan. Di mana hati sebagai raja, badan laksana seluruh wilayah, akal sebagai perdana menteri, syahwat sebagai gubernur wilayah, amarah adalah musuh, sedangkan anggota badan baik dhohir dan batin ibarat para tentara raja. Menjadi kewajiban raja untuk berkolaborasi dan bermusyawarah dengan perdana menteri karena perdana menteri inilah yang mempunyai daya nalar pikir guna mewujudkan keadaan negara yang baik terutama dalam mengontrol gubernur dan mengawasi para musuh. Jikalau demikian yang terjadi, niscaya jiwa seseorang akan baik, namun kalau raja lengah, perdana

${ }^{96}$ Hadhrotusy Syaikh Al Murobby Al Mursyid Achmad Asrori Al Ishaqy r.a, Untaian Mutiara dalam Ikatan Hati dan Jalinan Rohani (Surabaya: Al-Wafa, 2015), Cet ke 3, 282.

${ }^{97}$ Baharuddin, Paradigma Psikologi Islam Studi tentang Elemen Psikologi dari alQur'an, (Yogyakarta: Pustaka Pelajar, 2004), 113-114. 
menteripun tak kuasa untuk mengendalikan para musuh sehingga seluruhnya di bawah kendali musuh, maka kekacauan pada jiwa akan terjadi. Begitu pula gambaran tentang jiwa seseorang, fakultas qalb dan 'aql harus mampu mengontrol syahwat dan amarah, sehingga seluruh anggota badan akan mengarah pada kebaikan. Kalau qalb tidak berfungsi, maka 'aql akan lemah, sehingga syahwat dan amarah lebih menguasai jiwa seseorang. Akibatnya jiwa lebih diwarnai oleh nafsu syahwat dan amarah yang akan mengarah kepada keburukan. ${ }^{98}$

Dari seluruh penjelasan di atas, bisa diambil pengertian bahwa dalam jiwa manusia seakan-akan selalu terjadi dorongan tarik-menarik antara akal dan nafsu syahwat manusia. Akal selalu mengarah kepada kebaikan, sedangkan nafsu syahwat (hawa nafsu) selalu mengarah kepada perilaku keburukan. Sejatinya, syahwat dan amarah kalau bisa dikendalikan akan menjadi baik karena di situlah penyeimbang kehidupan. Namun kedua daya ini cenderung selalu berlebihan dan selalu mengarah kepada keburukan. Selanjutnya, apakah akal yang diutamakan atau nafsu syahwatnya yang dikedepankan, masih dipengaruhi lagi oleh keadaan hatinya waktu itu, karena hati (qalb) juga berpikir dan yang memutuskan. Namun dalam kejadian sehari-hari, walaupun tiap manusia sudah diberikan akal dan hati yang sama, nyatanya tidak serta merta kedua dimensi psikis ini selalu mampu mengendalikan nafsu dan syahwat manusia. Namun tak bisa dinafikan pula, bahwa perbuatan manusia terlebih dahulu dipengaruhi oleh faktor pengetahuan terhadapnya. Dan ini termaktub dalam hubungan antara konsep akal dan hati menurut alGhazali.

\section{Perbedaan antara Akal dan Hati}

Akal maupun hati adalah satu entitas-entitas yang sama namun kedua istilah ini mempunyai karakteristik yang membedakan satu sama lain. Hati juga menerima kebenaran namun dalam urusan spiritual, sedangkan akal terbatas dalam urusan inteligensia. ${ }^{99}$ Ketika akal hanya berurusan dalam persoalan rasional-empiris, hati lebih menekankan pada sisi rasional-emosional-spiritual untuk memahami

${ }^{98}$ Abu al-Husain Ahmad bin Faris bin Zakariya, Mu'jam al-Maqaayis fii al-Lughah, (Beirut: Daar al-Fikr, 1994), 672.

${ }^{99}$ Al-Ghazali, Ihyaa' 'Uluum al-Diin, J. III, 19. 
fenomena alam dan ayat-ayat Allah SWT. Perbedaan kemampuan ini sejatinya untuk menggapai dua dimensi alam yang berbeda, yaitu alam indra ('alam syahaadah) dan alam supernatural ('alam malakuut atau 'alam ghaib).

Selanjutnya, kemampuan hati dalam menjangkau alam metafisik selalu didukung oleh pengetahuan akal, namun pengetahuan ini tidaklah cukup menghindarkan hati dari kesalahan kecuali dengan menerima pengetahuan agama melalui ajaran para nabi (wahyu). Adanya pengetahuan dari wahyu ini selanjutnya memberi konsekuensi pada hati (sebagai substansi yang memutuskan tingkah laku) untuk melaksanakan ajaran yang ada di dalam wahyu. Di sinilah peran hati, yaitu dia juga berakal dan mampu berfikir untuk membenarkan adanya turunnya wahyu. Sebab itu, orang yang tidak yang tidak menerima wahyu Allah SWT, berarti hatinya tidak berakal (quluubun laa ya'qiluun) atau buta mata hatinya terhadap realitas ayat-ayat Allah Swt (ta'ma al-quluub). ${ }^{100}$

Kelebihan hati atas akal adalah bahwa hati mampu melihat segala hakikat kebenaran. Akal hanya bisa menangkap pengetahuan secara terbatas, yaitu pengetahuan yang hanya bersifat rasional dan empiris melalui indra dan daya nalar (rasio), sedangkan hati mampu menangkap kebenaran 'pengetahuan' secara tidak terbatas. Kemampuan yang tidak terbatas itu diperoleh dengan dzauq atau intuisi. Dengan dzauq ini hati dapat memperoleh 'ilm mukaasyafah yang tidak bisa dilalui lewat akal. Namun kemampuan hati ini sering dihalangi oleh kotoran yang mengendap di hati, sehingga menghalanginya untuk menangkap realitas kebenaran. ${ }^{10}$

\section{Akal dan Hati Bukan Rasio dan intelek}

Perbedaan konsep akal antara Islam dan Barat telah berdampak pula terhadap perbedaan pandangan antara keduanya terhadap ilmu pengetahuan. Ilmu adalah sifat akal, ketika akal memperoleh ilmu yang terdiri dari konsep-konsep yang membentuk suatu keseluruhan

${ }^{100}$ Muhammad Izzudin Taufiq, Panduan Lengkap dan Praktis Psikologi Islam, (Jakarta: Gema Insani Press 2006), 164.

${ }^{101}$ Muhammad Naquib al-Attas, Risalah untuk Kaum Muslimin, (Kuala Lumpur: ISTAC, 2001), 190. 
yang saling berhubungan, maka jadilah apa yang terabstraksikan di dalam akal menjadi pandangan hidup. ${ }^{102}$

Kalau ditelusuri akar sejarahnya, akan didapati bahwa paham filsafat Barat sudah semenjak awal menekankan kepada penggunaan akal nazari dan akal hayawani sebagai puncak perolehan ilmu. Paham ini terpengaruh ajaran Aristoteles, bahwa ilmu berdasarkan pada kenyataan luar, pengalaman, dan panca indra yang berlaku dalam pikiran dan memori serta gambaran akal. ${ }^{103}$

Paham filsafat Barat sendiri dalam menyebut akal setidaknya terdapat dua istilah, yaitu intelek dan rasio. Mereka mengkhususkan intelek (intelectus) untuk alat yang merenungkan hakikat rohaniah dan rasio (ratio) untuk memahami serta menguasai alam zahir. Istilah rasio berhubungan dengan istilah kognisi (fungsi akal). Jc. Chaplin berusaha menjembatani pengertian kognisi dengan pengertian rasio dan menyamakannya dengan akal, ia menyebutkan:

"Kognisi adalah suatu konsep umum yg mencakup semua bentuk pengenalan yang meliputi pengamatan, penglihatan, perhatian, pemberian pendapat, asumsi, imajinasi, prediksi, berpikir, mempertimbangkan, menduga, dan menilai."

Sejatinya pengertian kognisi ini tidaklah mampu memberi pengertian yang utuh tentang akal menurut pengertian Islam. Akal bukan sekadar rasio, akal juga bukanlah sekadar intelectus, namun akal adalah integrasi antara rasio dan intelek dengan kemampuan menahan hawa nafsu dan kesadaran bahwa Allah SWT ada di baliknya. Kesadaran ini selanjutnya memandang bahwa ilmu itu tidak dipisahkan antara dunia dan agama (akhirat), artinya tidak ada sekularisme dalam Islam.

Dalam pemikiran Barat, apa yang tampak dari manusia hanyalah rasio. Hal ini tampak dari perspektif kaum modernis yang memandang rasio sebagai alat yang sangat vital, sentral, dominan, dan paling

102 Ibid, 195.

${ }^{103}$ Al-Attas, Risalah..., 191.

${ }^{104}$ Yadi Purwanto, Psikologi kepribadian..., 144. 
utama dalam membentuk wajah peradaban umat manusia. ${ }^{105}$ Filsafat mereka telah menjadikan agama Kristen tidak mendasarkan kepercayaan pada ilmu dan keyakinan, namun hanya mendasarkan kepercayaannya pada dorongan daya kasih belaka.86 Bahayanya, disadari atau tidak, rasionalisme telah melatarbelakangi munculnya paham-paham di alam pemikiran Barat seperti sekularisme, dualisme, humanisme, dan liberalisme yang menjadi asas peradaban Barat.

Mengenai pandangan Islam terhadap rasio, Islam tetap mengakui bahwa ilmu pengetahuan dapat diperoleh dengan cara rasionalis-empiris, tetapi menolak kalau dikatakan bahwa cara ini adalah satu-satunya metode untuk memperoleh ilmu. Sebagaimana pendapat al-Ghazali, bahwa akal tidak bisa dipisahkan dengan hati. Integrasi antara dua fakultas ini berimplikasi pada intelektual dan spiritual yang saling mendudukkan satu sama lain. Kemampuan manusia menangkap ilmu melalui akal sudah mampu mengantarkannya kepada kebenaran. Bahkan dengan akal saja, manusia sudah mampu untuk merasakan adanya Tuhan. Hal ini sesuai dengan pendapat al-Ghazali untuk mengutamakan mendekatkan diri kepada Tuhan dengan akal. Artinya bahwa alam semesta dan fenomena di dalamnya cukup membuktikan adanya keterlibatan dan kewujudan Tuhan (tauhid). ${ }^{106}$ Namun memaksakan akal untuk mengetahui hakikat suatu ilmu terutama dalam menjangkau alam gaib (metafisik) adalah kemustahilan. Ini karena antara hal fisik dan metafisik adalah berbeda dimensi sehingga perlu merujuk pada potensi hati untuk menjangkau alam metafisik ('ilm mukaasyafah). Tiap masing-masing fakultas sudah dibekali potensi dengan batasan masing-masing, di mana akal mencakup persoalan-persoalan yang bersifat rasionalis-empiris, sedangkan hati mampu menjangkau segala hakikat kebenaran dalam persoalan rasional-emosional-sipiritual.

105 Zainal Abidin, Filsafat Manusia, (Bandung:, Remaja Rosda Karya, 2009), 242.

${ }^{106}$ Ma'had 'Aalam li al-Fikri al-Islamiy, 'Ilm Nafs..., 791. 


\section{KESIMPULAN}

Manusia adalah makhluk Tuhan yang tercipta dalam keadaan yang paling sempurna dan berbeda dengan yang lainnya. Karena manusia memliki akal dan hati, dimana keduanya merupakan hal saling berkaitan satu sama lain:

Pertama: Akal adalah sumber dan muara serta landasan ilmu. Ilmu yang mengalir dari akal laksana mengalirnya buah dari pohonnya dan cahaya dari matahari. Dengan akal manusia bisa dinilai derajatnya apakah derajatnya lebih mulia dari pada malaikat atau lebih rendah dari pada binatang. seorang yang menggunakan akalnya ke jalan yang lurus maka ia menduduki derajat yang lebih tinggi dari pada malaikat. Sedangkan seseorang yang tidak menggunakan akalnya dengan benar maka ia termasuk dalam derajat yang lebih rendah dari pada hewan.

Kedua: Hati adalah gejolak rasa yang dimiliki seseorang salik dalam mendekatkan diri kepada Tuhannya. Sehingga seorang hamba mampu merasakan asma-asma Allah SWT, bahkan terkadang seorang hamba mampu menyatu dengan asma-asma Allah SWT. hati lah yang menentukan baik-buruknya keadaan dhohir manusia. Hati ibarat raja yang memiliki tentara-tentara yakni anggota tubuh.

Jadi, hubungan antara hati dengan akal adalah akal sebagai indra penilai sedangkan hati adalah indra praktek manusia. Ketika manusia mampu memusatkan hatinya hanya kepada Tuhannya dan mengosongkan segala pikirannya -ketenangan antara hati dan akal- maka ia akan melebur menjadi satu dengan asma-asma Allah Swt (fana') sehingga apa yang dilihatnya adalah cerminan dari Dzat-Nya Allah SWT. 


\section{DAFTAR PUSTAKA}

Abidin, Zainal. Filsafat Manusia, Bandung: Remaja Rosda Karya, 2009.

Ahmad, Imam. bin Hambal, Muslim, Abu Daud, Nasa'i, Ibnu Majah, Thobroni, dan Baihaqi dari Aghor Al Mazani.

Ghazali (al), Terjemah Mi'raaj Al-Saalikiin, Kairo: Silsilah Al-Tsaqaafah Al-Islaamiyyah, 1964,

Husain (al), Abu. Ahmad bin Faris bin Zakariya, Mu'jam al-Maqaayis fii al-Lughah, Beirut: Daar al-Fikr, 1994.

Asrori, Achmad. Untaian Mutiara dalam Ikatan Hati dan Jalinan Rohani, Surabaya, Al-Wafa: 2015.

-------, Achmad. Mutiara Hikmah dalam Ma'rifat Kehadirat Allah Swt, Surabaya: Al-Wafa, 2010.

Baharuddin, Paradigma Psikologi Islam Studi tentang Elemen Psikologi dari al-

Qur'an, Yogyakarta: Pustaka Pelajar, 2004.

Izzudin, Muhammad Taufiq. Panduan Lengkap dan Praktis Psikologi Islam, Jakarta: Gema Insani Press 2006.

Majma' al-Lughah al-'Arabiyyah, Mu'jam al-Washiith, (Saudi Arabia: Daar Ihyaa' al-Turaats al-'Arabiy, 1983.

Naquib, Muhammad al-Attas. Risalah untuk Kaum Muslimin, Kuala Lumpur:

ISTAC, 2001.

Syauqi, Ahmad Ibrahim. Misteri Potensi Ghaib Manusia. Jakarta: Qisthi Press, 2012

Sutoyo, Anwar. Bimbingan dan Konseling Islami (Teori dan Praktik), Semarang: Cipta Prima Nusantara, 2007.

Utsman, Muhammad. bin Nadi Al Ishaqy r.a, Nuqthoh dalam Hakikat Makna Robithoh, Surabaya, Al-Wafa, 2010. 